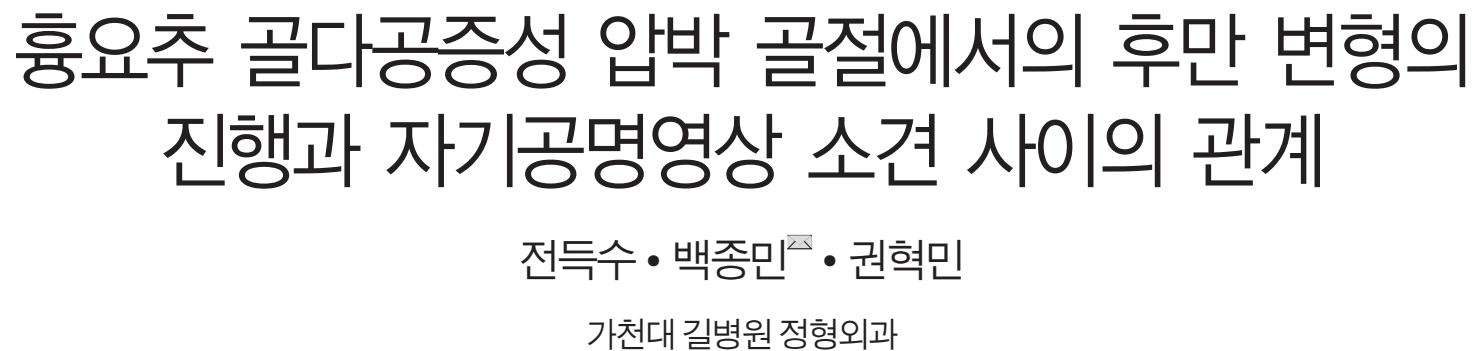

\title{
Relationship between the Progression of Kyphosis in Thoracolumbar Osteoporotic Vertebral Compression Fractures and Magnetic Resonance Imaging Findings
}

\author{
Deuk Soo Jun, M.D., Ph.D., Jong-Min Baik, M.D. ${ }^{\square}$, and Hyuk Min Kwon, M.D. \\ Department of Orthopedic Surgery, Gachon University Gil Medical Center, Incheon, Korea
}

\begin{abstract}
Purpose: To examine the relationship between the progression of a kyphotic deformity and the magnetic resonance imaging (MRI) findings in conservatively treated osteoporotic thoracolumbar compression fracture patients.

Materials and Methods: This study categorized the patients who underwent conservative treatment among those patients who underwent treatment under the suspicion of a thoracolumbar compression fracture from January 2007 to March 2016. Among them, this retrospective study included eighty-nine patients with osteoporosis and osteopenia with a bone density of less than -2.0 and single vertebral body fracture. This study examined the MRI of anterior longitudinal ligament or posterior longitudinal ligament injury, superior or inferior endplate disruption, superior of inferior intravertebral disc injury, the presence of low signal intensity on T2-weighted images, and bone edema of intravertebral bodies in fractured intravertebral bodies.

Results: In cases where the superior endplate was disrupted or the level of bone edema of the intravertebral bodies was high, the kyphotic angle, wedge angle, and anterior vertebral compression showed remarkably progression. In the case of damage to the anterior longitudinal ligament or the superior disc, only the kyphotic angle was markedly prominent. On the T2-weighted images, low signal intensity lesions showed a high wedge angle and high anterior vertebral compression. On the other hand, there were no significant correlations among the posterior longitudinal ligament injury, inferior endplate disruption, inferior disc injury, and the progression of kyphotic deformity and vertebral compression. The risk factors that increase the kyphotic angle by more than $5^{\circ}$ include the presence of injuries to the anterior longitudinal ligament, superior endplate disruption, and superior disc injury, and the risk factors were 21.3, 5.1, and 8.5 times higher than those of the uninjured case, and the risk differed according to the level of bone edema.

Conclusion: An osteoporotic thoracolumbar compression fracture in osteoporotic or osteopenic patients, anterior longitudinal ligament injury, superior endplate and intravertebral disc injury, and high level of edema in the MRI were critical factors that increases the risk of kyphotic deformity.
\end{abstract}

Key words: osteoporosis, spinal fracture, kyphosis, magnetic resonance imaging, thoracic lumbar sacral orthosis

\footnotetext{
Received August 29, 2018 Revised September 11, 2018

Accepted October 15, 2018

Correspondence to: Jong-Min Baik, M.D.

Department of Orthopedic Surgery, Gachon University Gil Medical Center, 21

Namdong-daero 774beon-gil, Namdong-gu, Incheon 21565, Korea

TEL: +82-32-460-3384FAX: +82-32-460-3114 E-mail: bbaik@hanmail.net

ORCID: https://orcid.org/0000-0002-6646-2449
}

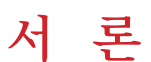

평균 수명이 증가함에 따라 골다공증을 않는 환자의 수는 나날이 증가하고 있다. 골다공증 환자는 정상인에 비하여 골절, 특히 훙 
추 및 요추의 압박 골절이 쉽게 일어날 수 있다.

안정형 척추 골절은 일반적으로 후만 변형이 없는 $30^{\circ}$ 미만의 후만각과 $50 \%$ 미만의 척추 압박으로 골절을 의미한다. ${ }^{1-3)}$ 이러한 안정형 흥요추 골절에 대해 침습적 치료가 고려될 수 있지만 보 존적 치료가 좋은 결과를 제공하는 것으로 보고되어 있다. ${ }^{24-7)}$ 또 한 보존적 치료 후 만족할 만한 결과를 기대할 수 있다면 비용 및 위험성 측면에서 수술적 치료보다 더 나은 선택이 될 수 있다. 그 러나 보존적 치료는 추가적인 후만 변형이 진행할 가능성이 높으 며 통증의 악화 및 신경학적 증상이 발생할 수 있다. ${ }^{8-11)}$

우리는 척추 변형의 진행에 대한 신뢰할 수 있는 예측 인자의 확인이 유용할 것으로 생각하였다. 자기공명영상(magnetic resonance imaging, MRI)은 흥요추의 손상에서 인대, 디스크, 종판(end plate) 및 척추의 손상 수준을 확인하기 위한 임상 및 실험적으로 검증된 진단 도구이다. ${ }^{12)}$

본 연구에서는 MRI를 이용하여 골다공증 환자에서 척추체 변 형의 예측 인자를 확인하고 이를 임상적으로 활용하고자 하였다.

\section{대상 및 방법}

\section{1. 연구대상}

2007년 1월부터 2016년 3월까지 505명의 환자가 흥요추 압박 골 절 의심하에 가천대 길병원에서 진료를 보았다. 그 중 88 명의 환 자는 McAfee 분류법에 따라 ${ }^{13)}$ 불안정성 골다공증성 흥요추 방 출성 골절에 해당하여 수술적 치료를 시행하였으며, 246명의 환 자는 척추성형술(vertebroplasty) 또는 경피적 풍선 척추성형술 (kyphoplasty) 시술을 시행받았다. 보존적 치료를 시행한 환자는 191 명이었으며 보존적 치료를 시행한 환자들 중 척추부 골밀도 -2.0 미만의 골감소증 및 골다공증을 보이며 다른 병적 골절을 제 외한 단일 분절 골절을 가진 환자 89 명을 대상으로 후향적으로 본 연구를 진행하였다. 해당 환자들은 흥요천추 보조기(thoracic lumbar sacral orthosis, TLSO)를 이용하여 보존적 치료를 시행하 였고 1년 이상 추시하였다. 코호트는 남성 36명, 여성 53명으로 전 체 평균 연령은 75세(27-99세)였다. 이 환자들은 MRI로 급성 골 절을 확인하였다.

\section{2. 방법}

골절된 척추체에서 전 · 후종 인대 손상, 상부 또는 하부 종판 파 열, 상부 또는 하부 추간판 손상, $\mathrm{T} 2$ 강조 영상에서 저 신호 강도 의 존재, 척추체의 골 부종 정도를 부상 후 48시간 이내에 MRI를 통해 확인하였다. 환자는 다음과 같이 분류하였다.

전종 또는 후종 인대 손상의 증거가 없는 군을 각각 anterior longitudinal ligament (AL) 1군 또는 posterior longitudinal ligament (PL) 1 군으로 전종 또는 후종 인대의 불연속성은 없지만 이완, 박 리 또는 파열이 있는 AL 2군 또는 PL 2군으로 분류하였다. 상부
종판 또는 하부 종판의 파열 없이 플라스틱 변형만 나타난 군을 각각 endplate superior (EP S) 1군 또는 endplate inferior (EP I) 1군 으로 플라스틱 변형과 파열이 나타난 군을 각각 $\mathrm{EP} \mathrm{S} 2$ 군 또는 $\mathrm{EP}$ $\mathrm{I} 2$ 군으로 분류하였다. 단, $\mathrm{EP}$ 군에서는 $\mathrm{MRI}$ 상 인접 부위 추간판의 신호 강도 변화가 있는 경우는 제외하였으며, 변화가 있는 경우는 $\operatorname{disc}(\mathrm{DI})$ 군으로 따로 분류하였으며 그 기준은 다음과 같다. 인접 부위 추간판의 상부 또는 하부 손상의 경우 명확한 손상의 증거 가 없는 군을 각각 disc superior (DI S) 1군 또는 disc inferior (DI I) 1 군으로 명확한 손상 및 파편이 존재하는 군을 각각 DI S2군 또는 DI I2군으로 분류하였다. 척추체 골 부종의 경우는 세 단계로 분 류하였으며, T1 강조 영상에서 척추체의 골 부종 정도에 따라 부 종 정도가 $1 / 3$ 미만인 vertebral body $(\mathrm{VB}) 1$ 군, 부종 정도가 $1 / 3$ 에 서 2/3인 VB2군 또는 부종 수준이 2/3 이상인 VB3군으로 분류하 였다. $\mathrm{T} 2$ 강조 영상에서 저 신호 강도 병변에 대해 저 신호 강도가 없는 경우를 T2 1군으로, 저 신호 강도가 있는 경우를 T2 2군으로 분류하였다(Table 1, Fig. 1).

급성 골다공증성 골절 진단 후 $\mathrm{TLSO}$ 를 즉시 착용하여 보존 적 치료를 시행하였다. 측면 방사선 사진으로 후만각 $(\mathrm{kyphotic}$

\section{Table 1. MRI Categorization Scheme}

\begin{tabular}{|c|c|}
\hline Group & MRI finding \\
\hline $\mathrm{AL} 1$ & No evidence of injury \\
\hline AL 2 & Slackening or striping or rupture of ligament \\
\hline PL 1 & No evidence of injury \\
\hline PL 2 & Slackening or striping or rupture of ligament \\
\hline EP S 1 & Only plastic deformity, no disruption \\
\hline EP S 2 & Disruption; evident discontinuity \\
\hline $\mathrm{EP} \mid 1$ & Only plastic deformity, no disruption \\
\hline $\mathrm{EP} \mid 2$ & Disruption; evident discontinuity \\
\hline DIS 1 & No evidence of injury \\
\hline DIS 2 & Either disc herniation or rupture \& debris \\
\hline $\mathrm{DI} \mid 1$ & No evidence of injury \\
\hline $\mathrm{DI} \mid 2$ & Either disc herniation or rupture \& debris \\
\hline T2 1 & Low signal intensity lesion on T2-weighted MRI (-) \\
\hline T2 2 & Low signal intensity lesion on T2-weighted MRI (+) \\
\hline VB 1 & $\begin{array}{l}\text { Less than one third of the volume of the involved } \\
\text { vertebral body }\end{array}$ \\
\hline VB 2 & $\begin{array}{l}\text { One third to two thirds of the volume of the involved } \\
\text { vertebral body }\end{array}$ \\
\hline VB 3 & $\begin{array}{l}\text { More than two thirds of the volume of the involved } \\
\text { vertebral body }\end{array}$ \\
\hline
\end{tabular}

$\overline{M R I}$, magnetic resonance imaging; $A L$, anterior longitudinal ligament; $P L$, posterior longitudinal ligament; EP S, endplate superior; EP I, endplate inferior; DI S, disc superior; DI I, disc inferior; VB, vertebral body. 

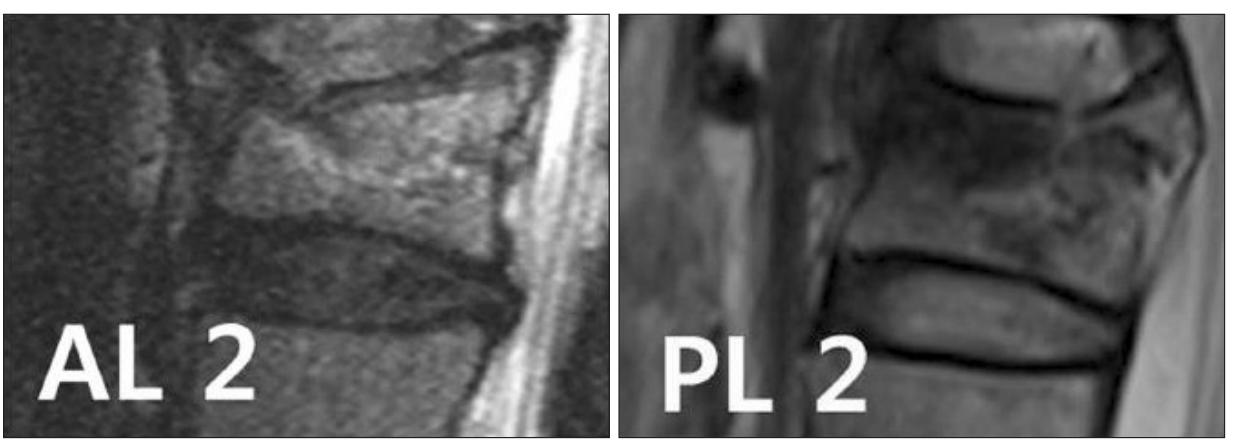
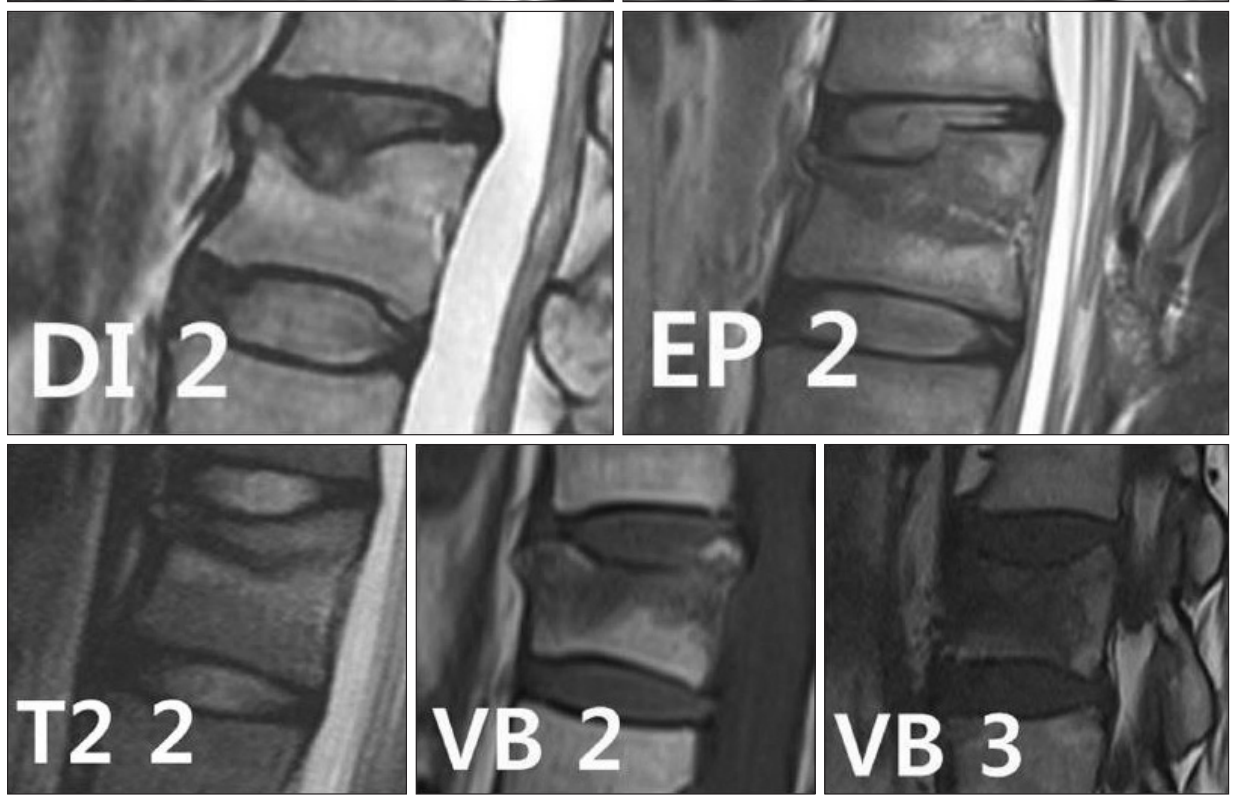

Figure 1. Features of ligament, disc, endplate and vertebral bodies (VBs) on magnetic resonance imagings. AL 2: slackening, striping, or rupture of the anterior longitudinal ligament, PL 2: slackening, striping, or rupture of the posterior longitudinal ligament, DI 2: disc herniation or rupture, EP 2: endplate disruption or evident discontinuity, T2 2: low signal intensity lesion,$+ V B 2$ : bone edema level $>1 / 3$ and $<2 / 3$, VB 3 : bone edema level $>2 / 3$. angle), 설상각(wedge angle), 전방 척추 압박률(anterior vertebral compression rate)을 측정하여 척추 기형을 계산하는 데 사용하였 다. 후만각은 $\mathrm{Cobb}$ 의 방법을 사용하여 골절된 척추체 인접 상부 추체의 상연과 인접 하부 추체의 하연이 이루는 각도로 측정하였 으며, 설상각도는 골절된 척추체의 상부 및 하부 종판이 이루는 각으로 측정하였다. 전방 척추 압박률은 인접한 상하 척추의 평 균 전방 높이의 백분율로 골절 된 척추의 전방 높이 손실을 표현 함으로써 측정되었다(Fig. 2). 각각의 방사선적 지표들은 최초 진 단 시점과 마지막 추시된 시점을 측정하여 통계적으로 비교, 분 석하였다. 상기 방사선적 지표들은 2 명의 척추외과의가 각각 2 번 측정하였으며, 그 평균값으로 측정값을 결정하였다.

통계 분석은 IBM SPSS ver. 21 (IBM Corp., Armonk, NY, USA). The Student's t-검정과 일원 분산 분석을 사용하여 통계적 MRI 변수를 분석했다. 변수는 유의 수준이 0.05 미만일 때 통계적으로 유의하다고 간주되었다. 로지스틱 회귀 분석을 사용하여 후만각 이 $>5^{\circ}$ 으로 증가하는 위험 요인을 확인하였다.

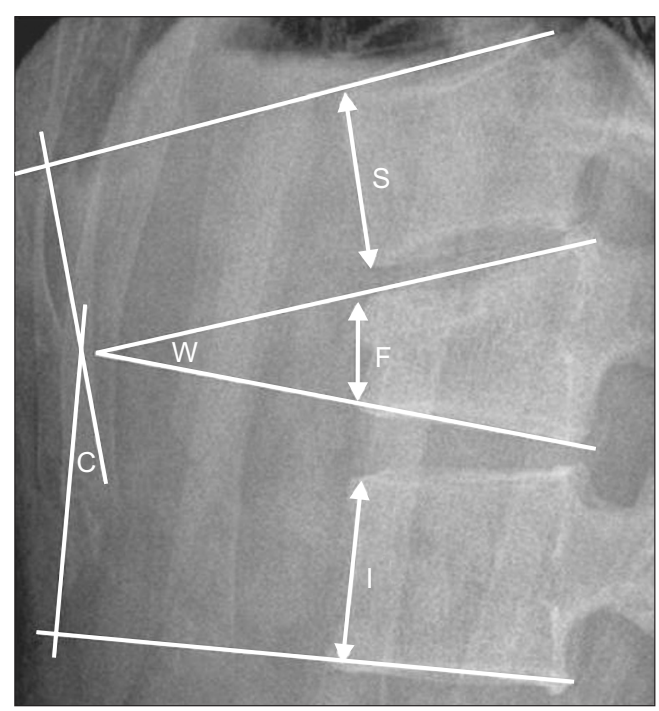

Figure 2. Measurement of the radiological parameters. $C^{\circ}$ : kyphotic angle by Cobb's method, $W^{\circ}$ : wedge angle, anterior vertebral compression rate (\%): $100(1-2 F /[S+I])$, S: anterior vertebral height superior to the fractured body, I: anterior vertebral height inferior to the fractured body, F: anterior vertebral height of the fractured body. 


\section{결 과}

골절 부위에 따라 제7-10흥추부를 포함한 사례가 7건, 제11흥추제1요추부를 포함한 사례가 61건, 제2-5요추부를 포함한 사례가 21 건이었다. 평균 추시 기간은 13.5 개월이었다(12-58개월). 전종 인대 손상이 24건(AL 2), 후종 인대 손상이 16건(PL 2), 상부 종판 손상이 36건(EP S), 하부 종판 손상이 8건이었다(EP I). 골절된 척 추체에서 상부 추간판 손상이 있는 경우가 21건(DI S), 하부 추간 판 손상이 있는 경우가 14 건이었다(DI I). 추가로 38 건이 T2 강조 영상에서 저 신호 강도의 병변을 보였으며(T2 2), 36건에서 척추

Table 2. Average Progression of the Kyphotic Angle, Wedge Angle, and Anterior Height Loss in Each Group

\begin{tabular}{|c|c|c|c|c|}
\hline Group & $\begin{array}{l}\text { Patient } \\
\text { (n) }\end{array}$ & $\begin{array}{l}\text { Increase of } \\
\text { kyphotic } \\
\text { angle }\left({ }^{\circ}\right)\end{array}$ & $\begin{array}{l}\text { Increase of } \\
\text { wedge } \\
\text { angle }\left(^{\circ}\right)\end{array}$ & $\begin{array}{c}\text { Increase of } \\
\text { height loss (\% }\end{array}$ \\
\hline AL 1 & 65 & 2.13 & 2.98 & 6.11 \\
\hline AL 2 & 24 & 4.56 & 4.11 & 8.35 \\
\hline$p$-value & - & $<0.001$ & 0.222 & 0.085 \\
\hline PL 1 & 73 & 3.31 & 3.85 & 7.12 \\
\hline PL 2 & 16 & 4.32 & 5.26 & 8.04 \\
\hline$p$-value & - & 0.498 & 0.301 & 0.812 \\
\hline EP S 1 & 53 & 1.74 & 3.35 & 5.55 \\
\hline EP S 2 & 36 & 5.58 & 6.46 & 16.22 \\
\hline$p$-value & - & $<0.001$ & $<0.001$ & $<0.001$ \\
\hline EPI1 & 81 & 2.33 & 3.12 & 4.85 \\
\hline EPI 2 & 8 & 3.04 & 3.33 & 7.21 \\
\hline$p$-value & - & 0.785 & 0.892 & 0.607 \\
\hline DI S 1 & 68 & 3.12 & 4.23 & 6.78 \\
\hline DI S 2 & 21 & 6.09 & 8.12 & 17.56 \\
\hline$p$-value & - & $<0.001$ & 0.041 & 0.051 \\
\hline DII 1 & 75 & 4.59 & 5.13 & 8.21 \\
\hline DII 2 & 14 & 5.41 & 5.95 & 10.23 \\
\hline$p$-value & - & 0.39 & 0.812 & 0.457 \\
\hline T2 1 & 51 & 2.14 & 2.74 & 2.89 \\
\hline T2 2 & 38 & 3.23 & 4.21 & 6.85 \\
\hline$p$-value & - & 0.254 & 0.051 & 0.053 \\
\hline VB 1 & 32 & 2.21 & 1.97 & 5.13 \\
\hline VB 2 & 36 & 5.22 & 5.11 & 10.15 \\
\hline VB 3 & 21 & 8.16 & 8.32 & 18.62 \\
\hline$p$-value & - & $<0.0001$ & $<0.001$ & $<0.001$ \\
\hline
\end{tabular}

$\mathrm{AL}$, anterior longitudinal ligament; PL, posterior longitudinal ligament; EP $\mathrm{S}$, endplate superior; EP I, endplate inferior; DI S, disc superior; DI I, disc inferior; VB, vertebral body.
체의 골 부종이 $1 / 3-2 / 3$ (VB 2), 21건에서 척추체의 골 부종이 $2 / 3$ 이상으로 나타났다(VB 3) (Table 2). 모든 환자에서 후만각의 진 행은 평균 $5.1^{\circ}\left(-3.8^{\circ}-13.1^{\circ}\right)$ 였고 설상각은 평균 $5.8^{\circ}\left(-3.5^{\circ}-13.3^{\circ}\right)$ 였 다. 전방 척추 압박의 평균 진행 정도는 $10.9 \%(-6.1 \%-45.6 \%)$ 였다. 상부 종판의 파열이 존재할 경우 후만각, 설상각, 전방 척추 압박 이 각각 $5.58^{\circ}, 6.46^{\circ}, 16.22 \%$ 로 상부 종판의 파열이 없을 때의 값 $1.74^{\circ}, 3.35^{\circ}, 5.55 \%$ 에 비해 높게 나타났으며, 추체의 골 부종의 수 준이 $1 / 3$ 이하일 때는 각각 $2.21^{\circ}, 1.97^{\circ}, 5.13 \%$ 진행되었고, 추체의 골 부종 수준이 $1 / 3$ 에서 $2 / 3$ 사이일 때 $5.22^{\circ}, 5.11^{\circ}, 10.15 \%$ 진행되 었고, 골 부종 수준이 $2 / 3$ 이상일 때는 $8.16^{\circ}, 8.32^{\circ}, 18.62 \%$ 진행되 었다(Table 2). 상부 종판이 파열된 사례나 척추체 골 부종 수준이 높은 사례의 경우 후만각, 설상각, 전방 척추 압박이 현저하게 진 행되었다. 전종 인대 손상이나 상부 추간판 손상이 있는 경우에 는 후만각만 현저하게 진행되었다. 전종 인대 손상이 있을 경우 후만각은 $4.6^{\circ}$ (AL 2) 증가하였고, 전종 인대 손상이 없는 경우 후 만각은 $2.1^{\circ}$ 증가하였다. 상부 추간판 손상이 있는 경우 후만각은 $6.1^{\circ}$ (DI S 2) 증가하였고, $3.1^{\circ}$ (DI S 1) 증가하였다. T2 강조 영상 에서 저 신호 강도의 병변을 보인 경우가 그렇지 않은 경우에 비 해 설상각과 전방 척추 압박이 높게 나타났는데 각각 $4.21^{\circ}, 6.85 \%$ (T2 2)와 2.74, $2.89 \%$ (T2 1)로 측정되었다. 후종 인대 손상과 하부 종판 파열 및 하부 추간판 손상의 경우는 후만 변형 및 척추 압박 의 진행과 유의미한 상관관계는 없었다.

후만각이 $5^{\circ}$ 이상 증가될 위험 요인으로는 전종 인대의 손상 유 무, 상부 종판 파열, 상부 추간판 손상 정도에 따라 $21.3,5.1,8.5$ 배 또한 추체 부종 수준에 따라 $1 / 3$ 이하 시 $10.6,1 / 3$ 에서 $2 / 3$ 사이일 때 22.3배로 관련이 있었다. 특히 추체 부종이 $2 / 3$ 이상일 때 후만 각이 $5^{\circ}$ 이상 증가될 위험이 100 배 이상으로 상승하였다(Table 3 ).

\section{고 찰}

척추 외과의사들 사이에는 골다공증성 척추 골절에 대한 적절한 치료를 선택하는 것에 대해 논란이 있다. 특히 보존적 치료 후 최

Table 3. Logistic Regression Analysis

\begin{tabular}{lrc} 
Group & Odds ratio & p-value \\
AL 2 & 21.268 & $<0.0001$ \\
EP S 2 & 5.146 & 0.035 \\
DI S 2 & 8.526 & 0.023 \\
VB 1 & 10.554 & $<0.001$ \\
VB 2 & 22.315 & $<0.001$ \\
VB 3 & 135.845 & $<0.001$ \\
\hline
\end{tabular}

Magnetic resonance imaging categories that predict an increase in kyphotic angle to $>5^{\circ}$. AL, anterior longitudinal ligament; EP S, endplate superior; DI S, disc superior; VB, vertebral body. 
Deuk Soo Jun, et al.

종 척추 후만 변형과 손상 직후의 후만 변형 사이의 차이는 통계 적으로 유의하지 않았으며, 대부분의 척추 변형은 수상 당시 발 생한다. 게다가 수술 실패(equipment failure)나 후만 변형의 재발 은 수술적 치료 이후 $56 \%$ 까지 높을 수 있다고 보고한다. ${ }^{11)}$ 일반적 으로 압박 골절과 안정성 방출성 골절은 McAfee 분류법에 의해 정의되며, ${ }^{13)}$ 후방 인대 복합체의 손상이 없을 경우 수술적 치료 는 척추 압박이 $50 \%$ 초과, 후만각이 $30^{\circ}$ 초과 또는 척추관 침범이 $50 \%$ 초과일 때 시행된다. 압박 골절이나 방출성 골절의 경우 신 경학적 침범이 없고, 척추 압박이 $50 \%$ 미만, 후만각이 $30^{\circ}$ 미만일 때 안정성 골절이라고 고려되며, 이 경우 보조기를 이용한 보존 적 치료만으로도 좋은 결과를 낼 수 있다. $2.5-7)$ 그러나 전방 척추체 높이의 손실 및 후만 변형이 추시 기간 동안 관찰되고 이러한 척 추체 변형의 방사선적 소견은 반드시 임상적 또는 기능적 결과와 관련이 있지는 않는다고 보고되고 있으나 $210,14,15)$ 척추체 압박과 후만 변형의 진행은 등과 허리의 통증을 악화시킬 수 있으며, 신 경학적 증상의 원인이 될 수 있다.8,1,11,16,17) 그러나 척추체 변형의 진행과 관련된 요소들 사이의 관계를 다루는 연구는 거의 없었으 므로, 이러한 진행에 대한 예측인자를 밝히기 위해 본 연구를 시 작하였다.

MRI는 축상 및 시상면에서의 척추의 정렬, 추간판 및 인대의 손상 상태, 골절의 부종 수준 및 척수의 경막 외 혈종 상태 등에 대한 정보를 제공한다. MRI는 컴퓨터 단층촬영 (computed tomography, CT)에 비해 피질골의 골절에 덜 민감할 수 있으나 상대적 으로 골절에 의한 골수 변화는 상당히 민감하게 반응한다. 특히 $\mathrm{MRI}$ 는 후방 인대 복합체의 손상을 포함한 추간판 및 인대 손상 의 평가에 임상적으로 이용되고 있다. ${ }^{12)}$ 본 연구는 '척추체 골절 에 대해 척추체 변형과 척추체 압박의 진행이 MRI에 의해 예측 될 수 있는가'라는 질문에서 시작하였으며, 전방 및 후방 인대의 방사선적 소견상, 하부 추간판 및 종판, 골 부종 수준, $\mathrm{T} 2$ 강조 영 상에서 저 신호 강도 병변을 활용하여 분석하였다.

전종 인대 손상은 회전력이나 전단력 또는 척추체나 추간판이 파열되는 힘에 의해 유발될 수 있다. ${ }^{18,19)}$ 후종 인대 손상은 대부분 굴곡력 또는 종판이나 추간판이 파열되는 힘에 의해 유발되며, 후종 인대는 골절 파편들의 간접적인 정복에 가장 중요한 구조물 로 알려져 있다. 만약 보존적 치료를 시행한 환자들 중에 인식하 지 못한 인대 손상이 있을 경우 후만 변형이 진행될 수 있으며, 지 속적인 통증이 발생할 수 있다. ${ }^{20}$ 본 연구에서는 전종 인대 손상 이 있는 경우 후만각이 평균 $4.6^{\circ}$ 증가하는 것을 확인함으로써 전 종 인대 손상이 후만 변형의 중요한 원인임을 알 수 있었다. 그리 고 MRI에서 종판의 파열이 있거나 $1 / 3$ 이상의 추체 부종이 있으 면 척추 변형의 진행에 유의한 영향을 줄 수 있다. ${ }^{18)}$ 또한 상부 종 판 골절이 있을 경우 작용된 외력이 클 수 있고, 부종 수준이 $1 / 3$ 을 초과하면 추체 내 해면골까지 손상될 수 있다. ${ }^{20)}$ 본 연구에서 도 상부 종판 파열이 있거나 추체 내 부종 수준이 $1 / 3$ 을 초과할
경우 후만각, 설상각, 전방 척추 압박률이 유의미하게 높았으며, 이 두 가지 조건이 후만 변형을 진행시킨다는 것을 확인할 수 있 었다. 특히 후만각이 $5^{\circ}$ 이상 증가하는 위험은 상부 종판이 파열 되었을 때 5.1배, 추체 내 골 부종 수준이 $1 / 3$ 에서 2/3일 때 22.3배, $2 / 3$ 이상일 때는 135.8 배 높았다. 추간판 손상이 없는 경우 $2 / 3$ 이 상의 골 부종 수준이 후만 변형 진행을 결정하는 중요한 요소임 을 알 수 있었다.

외력이 추간판에 가해지면 형태가 변형되고 조직 재분배가 일 어난다. 따라서 추간판이 손상된 상부 종판과 추체에 점차적으 로 침강하는 것은 추체 자체의 압박과 함께 후만 변형의 진행에 중요한 요소로 고려된다. ${ }^{11,20)}$ 본 연구에서 상부 추간판 손상이 있 을 경우 후만 변형이 이러한 과정에 의해 증가되는 것을 관찰할 수 있었다. 더욱이 후만각이 $5^{\circ}$ 이상 증가하는 위험은 상부 추간 판 손상이 있는 경우가 없는 경우에 비해 8.5배 높은 것으로 나타 났다. 설상각과 전방 척추 압박 또한 상부 추간판 손상이 있을 때 증가하는 경향을 보였으나, 통계적으로 유의하지는 않았다. 축성 압박에 의한 골절의 경우, 척추체 변형은 해면골의 감입의 결과 일 수 있다. ${ }^{21}$ 게다가 흥요추 골절의 경우 $\mathrm{T} 2$ 강조 영상에서 저 신 호 강도의 병변이 CT에 의해 혈종으로 가시화 된 해면골 감입 부 위와 일치하는 것으로 보고되었다. ${ }^{20)}$ 따라서 $\mathrm{T} 2$ 강조 영상에서 저 신호 강도 병변은 추체 압박의 추후 진행을 현저하게 촉진시킨다 고 추정된다. 본 연구에서도 이러한 경우 설상각과 전방 척추 압 박이 유의하게 증가하는 것으로 나타났으나 통계적으로 유의하 지는 않았다.

후종 인대 손상, 하부 종판 손상, 하부 추간판 손상은 후만 변형 이나 척추 압박의 진행과 의미 있는 상관 관계를 보이지 않았다. 그 이유로 본 연구에서는 후종 인대 손상을 입은 환자가 16 명에 불과하였고, 이외의 대부분 후종 인대 손상 환자는 후방 인대 복 합체의 손상이 있기 때문에 대개 불안정성 골절과 관련되어서 수 술을 시행받았기 때문에 본 연구에서는 상관관계가 없는 것으로 나타났다고 생각한다. 또한 본 연구의 제한점으로 후만 변형 및 임상 기능 결과의 진행과 관련된 방사선적 요인, 연령, 보조기 착 용, 골밀도 등을 고려하지 않은 점 등을 들 수 있겠다.

\section{결 론}

골감소증 및 골다공증 환자에서 흥요추부 압박 골절일지라도 전 종 인대 손상, 상부 종판 및 추간판 손상 또는 MRI상 높은 수준의 부종이 있을 경우 후만 변형의 위험도가 증가한다는 것을 알 수 있었다. 특히 $2 / 3$ 이상의 골 부종은 후만 변형의 진행을 예측하는 가장 중요한 요소이므로 추가적이고 적극적인 추적 관찰과 치료 가 필요하다. 


\section{CONFLICTS OF INTEREST}

The authors have nothing to disclose.

\section{REFERENCES}

1. Cantor JB, Lebwohl NH, Garvey T, Eismont FJ. Nonoperative management of stable thoracolumbar burst fractures with early ambulation and bracing. Spine (Phila Pa 1976). 1993;18:971-6.

2. Krompinger WJ, Fredrickson BE, Mino DE, Yuan HA. Conservative treatment of fractures of the thoracic and lumbar spine. Orthop Clin North Am. 1986;17:161-70.

3. Reid AB, Letts RM, Black GB. Pediatric chance fractures: association with intra-abdominal injuries and seatbelt use. J Trauma. 1990;30:384-91.

4. Ağuş H, Kayali C, Arslantaş M. Nonoperative treatment of burst-type thoracolumbar vertebra fractures: clinical and radiological results of 29 patients. Eur Spine J. 2005;14:536-40.

5. Weinstein JN, Collalto P, Lehmann TR. Thoracolumbar "burst" fractures treated conservatively: a long-term follow-up. Spine (Phila Pa 1976). 1988;13:33-8.

6. Chow GH, Nelson BJ, Gebhard JS, Brugman JL, Brown CW, Donaldson DH. Functional outcome of thoracolumbar burst fractures managed with hyperextension casting or bracing and early mobilization. Spine (Phila Pa 1976). 1996;21:2170-5.

7. James KS, Wenger KH, Schlegel JD, Dunn HK. Biomechanical evaluation of the stability of thoracolumbar burst fractures. Spine (Phila Pa 1976). 1994;19:1731-40.

8. Denis F, Armstrong GW, Searls K, Matta L. Acute thoracolumbar burst fractures in the absence of neurologic deficit. A comparison between operative and nonoperative treatment. Clin Orthop Relat Res. 1984;189:142-9.

9. Gertzbein SD. Scoliosis research society. Multicenter spine fracture study. Spine (Phila Pa 1976). 1992;17:528-40.

10. Mumford J, Weinstein JN, Spratt KF, Goel VK. Thoracolumbar burst fractures. The clinical efficacy and outcome of nonoperative management. Spine (Phila Pa 1976). 1993;18:95570.

11. Oner FC, van Gils AP, Faber JA, Dhert WJ, Verbout AJ. Some complications of common treatment schemes of thoracolumbar spine fractures can be predicted with magnetic resonance imaging: prospective study of 53 patients with 71 fractures. Spine (Phila Pa 1976). 2002;27:629-36.

12. Williams RL, Hardman JA, Lyons K. MR imaging of suspected acute spinal instability. Injury. 1998;29:109-13.

13. McAfee PC, Yuan HA, Fredrickson BE, Lubicky JP. The value of computed tomography in thoracolumbar fractures. An analysis of one hundred consecutive cases and a new classification. J Bone Joint Surg Am. 1983;65:461-73.

14. Young MH. Long-term consequences of stable fractures of the thoracic and lumbar vertebral bodies. J Bone Joint Surg Br. 1973;55:295-300.

15. Alanay A, Yazici M, Acaroglu E, Turhan E, Cila A, Surat A. Course of nonsurgical management of burst fractures with intact posterior ligamentous complex: an MRI study. Spine (Phila Pa 1976). 2004;29:2425-31.

16. Jacobs RR, Asher MA, Snider RK. Thoracolumbar spinal injuries. A comparative study of recumbent and operative treatment in 100 patients. Spine (Phila Pa 1976). 1980;5:46377.

17. Tropiano P, Huang RC, Louis CA, Poitout DG, Louis RP. Functional and radiographic outcome of thoracolumbar and lumbar burst fractures managed by closed orthopaedic reduction and casting. Spine (Phila Pa 1976). 2003;28:2459-65.

18. Oner FC, van Gils AP, Dhert WJ, Verbout AJ. MRI findings of thoracolumbar spine fractures: a categorisation based on MRI examinations of 100 fractures. Skeletal Radiol. 1999;28:433-43.

19. Petersilge CA, Pathria MN, Emery SE, Masaryk TJ. Thoracolumbar burst fractures: evaluation with MR imaging. Radiology. 1995;194:49-54.

20. Wood K, Buttermann G, Mehbod A, Garvey T, Jhanjee R, Sechriest V. Operative compared with nonoperative treatment of a thoracolumbar burst fracture without neurological deficit. A prospective, randomized study. J Bone Joint Surg Am. 2003;85:773-81.

21. Magerl F, Aebi M, Gertzbein SD, Harms J, Nazarian S. A comprehensive classification of thoracic and lumbar injuries. Eur Spine J. 1994;3:184-201. 


\section{흉요추 골다공증성 압박 골절에서의 후만 변형의 진행과 자기공명영상 소견 사이의 관계 전득수 백종민 $・$ 권혁민 가천대 길병원 정형외과}

목적: 자기공명영상(magnetic resonance imaging, MRI)을 이용하여 보존적 치료를 시행한 흥요추부 골다공증성 압박 골절 환자에 서 후만 변형의 예측 인자를 조사하고자 하였다.

대상 및 방법: 2007년 1월부터 2016년 3월까지 흥요추 압박 골절 의심하에 진료를 본 환자들 중 보존적 치료를 시행한 환자를 따로 분류하였고 그들 중 골밀도 -2.0 미만의 골감소증 및 골다공증, 단일 분절 골절을 가진 환자 89명을 대상으로 후향적 연구를 시행하 였다. 골절된 척추체에서 전 · 후종 인대 손상, 상부 또는 하부 종판 파열, 상부 또는 하부 추간판 손상, T2 강조 영상에서 저 신호 강 도의 존재, 척추체의 골 부종 정도를 MRI를 통해 확인하였다.

결과: 상부 종판이 파열된 사례나 척추체 골 부종 수준이 높은 사례의 경우 후만각, 설상각, 전방 척추 압박이 현저하게 진행되었다. 전종 인대 손상이나 상부 추간판 손상이 있는 경우에는 후만각만 현저하게 진행되었다. T2 강조 영상에서 저 신호 강도의 병변을 보 인 경우 설상각과 전방 척추 압박이 높게 나타났다. 그러나 후종 인대 손상과 하부 종판 파열 및 하부 추간판 손상의 경우는 후만 변 형 및 척추 압박의 진행과 유의미한 상관관계는 없었다. 후만각이 $5^{\circ}$ 이상 증가될 위험 요인으로는 전종 인대의 손상 유무, 상부 종 판 파열, 상부 추간판 손상이 있는데 손상 받지 않은 사례에 비해 각각 21.3, 5.1, 8.5배 위험했고 골 부종 수준에 따라 각각 위험도가 달랐다.

결론: 골감소증 및 흥요추부 골다공증성 압박 골절일지라도 전종 인대 손상, 상부 종판 및 추간판 손상 또는 MRI상 높은 수준의 부종 이 있을 경우 후만 변형의 위험도가 증가한다.

색인단어: 골다공증, 척추 골절, 척추 후만증, 자기공명영상, 흉요천추 보조기

접수일 2018년 8월 29일 수정일 2018년 9월 11일 게재확정일 2018년 10월 15일

책임저자 백종민

21565 , 인천시 남동구 남동대로 774 번길 21, 가천대 길병원 정형외과

TEL 032-460-3384, FAX 032-460-3114, E-mail bbaik@hanmail.net, ORCID https://orcid.org/0000-0002-6646-2449 